\title{
Hematodinium sp. infection in Norway lobster Nephrops norvegicus and its effects on meat quality
}

\author{
Amaya Albalat ${ }^{1}$, Sebastian G. Gornik ${ }^{1}$, Nicholas Beevers ${ }^{1}$, R. James A. Atkinson ${ }^{2}$, \\ David Miskin ${ }^{3}$, Douglas M. Neil ${ }^{1, *}$
}

\begin{abstract}
${ }^{1}$ Research Institute of Biodiversity, Animal Health and Comparative Medicine, College of Medical, Veterinary and Life Sciences, University of Glasgow, Glasgow G12 8QQ, UK

${ }^{2}$ University Marine Biological Station Millport (UMBSM), Isle of Cumbrae, Millport KA28 0EG, UK

${ }^{3}$ Food Innovation Institute (F2i), Midlothian Innovation Centre, Roslin, Midlothian EH25 9RE, UK
\end{abstract}

\begin{abstract}
Hematodinium and Hematodinium-like species have emerged in the last 3 decades as important parasitic pathogens of crustaceans worldwide, causing a significant economic loss to fisheries and related markets. In some species (notably the Tanner crab Chionoecetes bairdi), the parasite reportedly causes the cooked meat to taste bitter and aspirin-like. The bitter taste, together with the gross pathology of the infection, renders these crabs unmarketable. Surprisingly, no organoleptic tests have ever been conducted to date, and the cause for the bitter taste is still unknown. Nevertheless, it is generally assumed that the bitter taste occurs widely in cooked meats and products derived from crustaceans infected with Hematodinium. In the present study, we analysed the meat quality and organoleptic attributes after capture and during storage of Norway lobsters Nephrops norvegicus from Scottish waters that were either asymptomatic or symptomatic of patent Hematodinium infection. Results from the sensory evaluation of the cooked product indicate that tail meat from symptomatic $N$. norvegicus is bland in flavour and aftertaste, and more friable or sloppier in texture than meat from asymptomatic animals. As a consequence, infected meat tends to be less palatable, although surprisingly no bitter taste is reported. From an analytical point of view, tail meat from patently infected animals is at an advanced stage of autolysis, while no difference in microbial load is detected. These results suggest that Norway lobsters heavily infected with Hematodinium are of inferior marketing quality even after the tails have been cooked.
\end{abstract}

KEY WORDS: Hematodinium sp. Nephrops norvegicus · Sensory evaluation · Quality-related measures Resale or republication not permitted without written consent of the publisher

\section{INTRODUCTION}

Over the last $30 \mathrm{yr}$, dinoflagellate parasites of the Hematodinium genus have emerged as important parasitic pathogens of crustaceans worldwide, causing a significant economic loss to fisheries, aquaculture and related markets (Latrouite et al. 1988, Meyers et al. 1990, Field et al. 1992, Messick 1994, Xu et al. 2010). The parasite causes significant mortalities in the Scottish west coast populations of the Norway lobster Nephrops norvegicus, which yield most of the UK catches (Field et al. 1992) and support the second most valuable fishery in the UK, worth approximately E104.3M at first sale in 2007 (FRS 2009). The initial reported mortality of $N$. norvegicus associated with Hematodinium sp. was as high as $70 \%$ (Field et al. 1992). However, prevalence in this species is now at a lower but constant level around 25-30\% (Stentiford et al. 2001a, Stentiford \& Neil 2011, Beevers et al. 2012 in this DAO Special). In general, after initial 
reports of the disease in a fishery, recurrent and annual disease episodes caused by Hematodinium sp. are a key epidemiological feature (Meyers et al. 1990, Love et al. 1993, Field \& Appleton 1995, Stentiford et al. 2001a, Briggs \& McAliskey 2002).

In Nephrops norvegicus, the earlier stages of the infection are detectable only by very sensitive diagnostic methods based on immunological or molecular techniques (Small et al. 2002, Hamilton et al. 2009, Beevers et al. 2012). At these stages, the infection is asymptomatic, and the physiological disruption in the host is minimal (Stentiford et al. 1999, 2000, $2001 b)$. However, with increasing infection intensity, an associated hyper-pigmentation of the cuticle and white milky haemolymph make these individuals conspicuous amongst uninfected conspecifics (Field et al. 1992). A visual inspection identifies only such patently infected $N$. norvegicus (here termed symptomatic). At this advanced stage, the animals become physiologically compromised, and display clear pathogenesis in their organs, tissues and haemolymph (reviewed by Stentiford \& Shields 2005).

In general, crustacean species harbouring advanced stages of Hematodinium spp.-associated infections are unmarketable due to poor meat taste, texture and appearance. One of the first industries experiencing this was the Alaskan crab fishery. Here, a number of southeastern Alaskan processors in 1985 and 1986 complained about a markedly bitter aftertaste in some of their cooked Tanner crab Chionoecetes bairdi product. Following this, a study was conducted to elucidate the cause of this bitter taste. It was later found that the crabs were infected with a Hematodinium-like parasite, suggesting a possible link between the bitter taste and the presence of the parasite. The condition was thus termed 'bitter crab disease' (BCD) (Meyers et al. 1987). Nevertheless, these authors could not definitely link Hematodinium sp. infection with the bitter taste. They speculated that it resulted from either the parasite itself or a natural metabolite produced in the tissues during the course of the infection. No organoleptic tests were carried out in the 1987 study, although the authors themselves suggested that a chemical analysis of infected and uninfected crab tissues with parallel taste tests were needed in order to support their speculations on the cause of the bitter flavour. Cooked meat from several other crab species infected with Hematodinium spp. have been reported as having a bitter taste: Necora puber from French waters (Wilhelm \& Mialhe 1996), and red king crab Paralithodes camtschaticus and blue king crab P. platypus from Russian waters (Ryazanova 2008). It has also been claimed that BCD in a single individual Newfoundland snow crab Chionoecetes opilio influences the flavour of a whole batch (Shields et al. 2005), but no data are given. Conversely, no bitter flavour has been found in blue crab Callinectes sapidus with Hematodinium sp. infections (Stentiford \& Shields 2005). However, in none of these cases were the chemical tests suggested by Meyers et al. (1987) conducted to support organoleptic assessment.

To determine whether Hematodinium sp. infection causes a similar bitter taste in cooked Nephrops norvegicus meat, we conducted a systematic study involving a trained sensory panel, as described by Albalat et al. (2011). In addition, some key qualityrelated analytical measurements from the meat (nucleotide concentrations, $K$-value, microbial load and trimethylamine [TMA] concentrations) were obtained and combined with the results of the sensory evaluations. To our knowledge this is the first time cooked meat derived from a Hematodinium spp.-infected crustacean has been tested in such a way.

\section{MATERIALS AND METHODS}

\section{Sample collection and storage}

Norway lobsters Nephrops norvegicus were caught by otter trawl (90 min duration) in the Clyde Sea

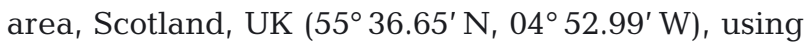
the RV 'Aora' from the University Marine Biological Station Millport during March 2006 (the month in which the infection is known to reach a climax). Animals were examined and classified according to their body colour (Field et al. 1992) as symptomatic of patent Hematodinium sp. infection, or as asymptomatic (which would include both truly uninfected and also sub-patently infected individuals). The validity of these visual criteria for indicating patent infection has recently been confirmed by correlating them with molecular methods for directly detecting parasites in the haemolymph (Beevers et al. 2012). These groups will hereafter be referred to as 'symptomatic' and 'asymptomatic'.

The animals were then killed by twisting the abdomen from the cephalothorax, and groups of 60-70 isolated tails (within their exoskeletons) were placed in re-sealable plastic bags and stored in perforated polystyrene boxes on ice. This treatment was chosen in an attempt to duplicate the handling methods in the trawl fishery for Nephrops norvegicus which targets the separated tails to be sold as 'scampi'. Upon 
arrival in the laboratory, the polystyrene boxes were stored on ice in a cold room $\left(3 \pm 1^{\circ} \mathrm{C}\right)$ for $7 \mathrm{~d}$, with the ice being renewed every $2 \mathrm{~d}$. This simulated an extended period of a practice followed commercially.

Immediately after capture on the trawl vessel (time 0) and on Days 1, 3, 5 and 7 of holding or storage, 5 tails were removed randomly from each group for analysis of quality-related measures ( $K$-value, bacterial load, muscle $\mathrm{pH}$ and TMA concentrations). At each time point, samples from the muscle were taken for $\mathrm{pH}$ and microbiological analysis, and the remaining tail meat was immediately frozen in liquid nitrogen and subsequently stored at $-80^{\circ} \mathrm{C}$ for later analysis.

\section{Quality-related measures (biochemical and microbiological analysis)}

To determine concentrations of adenosine 5'triphosphate [ATP] and its breakdown products (adenosine 5'-diphosphate [ADP], adenosine 5'-monophosphate [AMP], inosine 5'-monophosphate [IMP], inosine $[\mathrm{HxR}]$ and hypoxanthine $[\mathrm{Hx}]$ ), nucleotide extracts were prepared as described in Ryder (1985) and analysed as described in Albalat et al. (2009). Kvalues, measured as an index of freshness, were calculated according to Saito et al. (1959), where:

$$
100 \times\left[\frac{K \text {-value }=}{[\mathrm{ATP}]+[\mathrm{ADP}]+[\mathrm{HMP}]+[\mathrm{Hx}]}\right]
$$

To obtain the muscle $\mathrm{pH}$, samples were homogenised in distilled water in a 1:10 (w/v) ratio according to Chiou \& Huang (2004) and measurements were carried out with a standard glass bodied $\mathrm{pH}$ electrode (model FB68788, Fisher Scientific).

For microbiological analysis, isolated tails (on Days 0, 3 and 5) were surface sterilised by immersion in $0.1 \%$ benzalkonium chloride made up in sterile seawater (SSW). Meat was dissected and a small piece $(0.4-1.0 \mathrm{~g})$ was placed aseptically into a stomacher bag. For each gram of meat, $9 \mathrm{ml}$ of SSW containing $0.1 \%$ bacterial peptone (Difco) was added and the sample was homogenised in a Seward stomacher (Biomaster 80). The homogenised material was transferred into sterile plastic universals and an appropriate dilution series was set up using SSW as diluent. A volume of $1 \mathrm{ml}$ of each dilution was applied to pre-cast plates (Compact Dry ${ }^{\circledR}$ TC, HyServe) in quadruplicate. Plates were incubated at $20^{\circ} \mathrm{C}$ for $72 \mathrm{~h}$ and total viable counts (TVCs) of bacteria were recorded as colony forming units per gram of muscle $\left(\mathrm{cfu} \mathrm{g}^{-1}\right)$. Using rankit plots, results were found to follow a non-normal distribution and so data were normalised by conversion into logarithmic values $\left(\log _{10} \mathrm{cfu} \mathrm{g}^{-1}\right)$.

TMA concentration, which is indicative of the action of spoilage bacteria, was determined by the method of Dyer (1945) with some minor modifications introduced by Stroud et al. (1982) in order to suppress interference by dimethylamine.

\section{Sensory analysis}

Descriptive analysis of sensory attributes of cooked samples (ca. 20-30 tails for each group) was carried out by an independent trained panel consisting of 12 experienced judges, who followed a quantitative descriptive analysis (QDA) method as described in Albalat et al. (2011). These taste panel evaluation sessions were carried out at the Food Innovation Institute, Queen Margaret University, Edinburgh. Sensory attributes of the samples scored in the tasting sessions are shown in Table 1. The trained panel was also asked to subjectively score their 'degree of like or dislike' (overall liking) of each sample on a linear scale (0-10). Nephrops norvegicus tail samples were boiled for $3 \mathrm{~min}$ to ensure a core temperature of $75^{\circ} \mathrm{C}$, to comply with EU regulations, and then peeled. To increase the reliability of the findings and to reduce any bias because of sample presentation order, samples were given 3-digit random code numbers and were presented to the panel in a random manner. Sensory evaluation sessions were carried out in a computerised sensory room, and the data gathered were analysed using the computer software FIZZ and SPSS.

Table 1. Definition of sensory attributes and scoring system used in the sensory analysis of cooked Nephrops norvegicus tail meat

\begin{tabular}{|llll|}
\hline Attribute & \multicolumn{1}{c}{ Score 0 } & Score 5 & \multicolumn{1}{c|}{ Score 10 } \\
\hline Smell character & Sour-ammoniacal & Neutral & Fishy-seaweedy \\
Smell strength & Weak & Medium & Strong \\
Springiness & Stays down & Bounces back & Resilient \\
Firmness & Friable & Slightly soft & Firm \\
Chewiness & Melt in mouth & Slightly soft & Chewy \\
Moistness & Dry & Medium & Moist \\
Flavour & Bitter-sour & Bland & Sweet \\
Aftertaste & Bitter & Bland & Sweet \\
Overall liking & Disliked extremely & Indifferent & Liked extremely \\
\hline
\end{tabular}




\section{Statistical analysis}

Differences between infected and asymptomatic groups at each sampling time were analysed by independent sample $t$-tests, and p-values lower than 0.05 were considered statistically significant.

\section{RESULTS}

\section{Analytical measures}

Immediately after capture, Nephrops norvegicus symptomatic of patent Hematodinium sp. infection had significantly lower ADP and significantly higher IMP concentrations than asymptomatic animals. Moreover, although HxR was not detectable in tail meat from asymptomatic animals, it was measurable at levels of $0.37 \pm 0.03 \mu \mathrm{mol} \mathrm{g}^{-1}$ in symptomatic ones (Fig. 1). Therefore, the $K$-values calculated from these nucleotide concentrations were, even from the point of capture, significantly higher in symptomatic animals compared with asymptomatic ones (Fig. 2). This difference in the $K$-values between the 2 groups was maintained, and even increased, with storage time on ice, so that on Day 7 the $K$-value for the symptomatic animals $(39.33 \pm 8.89)$ was 3 times higher than that for the asymptomatic ones $(12.79 \pm 1.26)$.

Muscle $\mathrm{pH}$ was also significantly higher in symptomatic animals, both immediately after capture and on Day 1 of storage on ice (Fig. 3). However, in this case

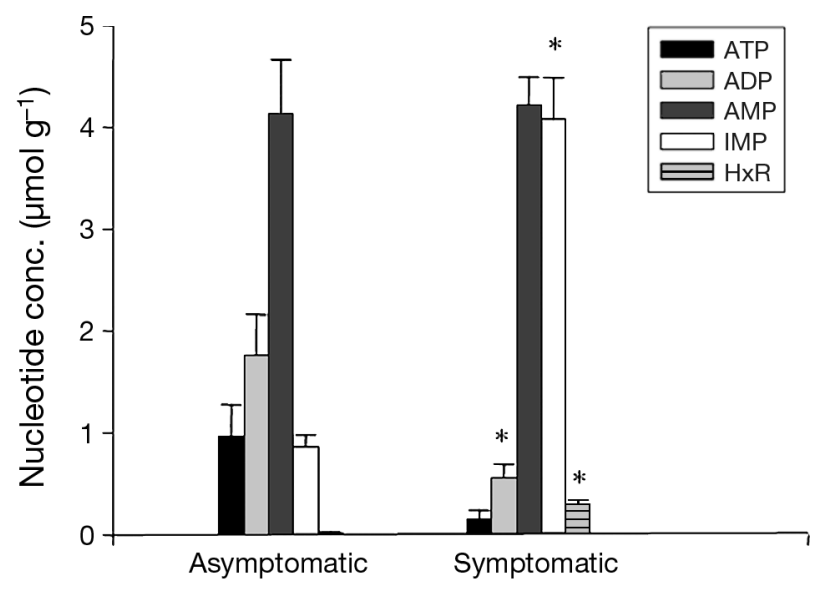

Fig. 1. Nucleotide concentrations (ATP: adenosine-5'-triphosphate; ADP: adenosine-5'-diphosphate; AMP: adenosine-5'monophosphate; IMP: 5'-inosine monophosphate; HxR: inosine) after capture in tail meat of Nephrops norvegicus that were either asymptomatic or symptomatic of patent infection by Hematodinium sp. Data are means $\pm \mathrm{SE}_{;} \mathrm{n}=5$. (*) Values are significantly different between asymptomatic and symptomatic $N$. norvegicus $(\mathrm{p}<0.05)$ the difference decreased with storage time on ice, and was non-significant from Day 3 onwards. Other quality-related analytical measures such as TVCs of bacteria were similar between the 2 groups, and no significant differences were obtained either immediately after capture or as storage time on ice increased (Fig. 4). This was also the case for muscle TMA concentrations, and although higher concentrations were obtained in symptomatic animals $(56.10 \pm 23.73 \mathrm{mg}$ TMA kg ${ }^{-1}$ muscle) compared with asymptomatic ones $\left(17.99 \pm 12.57 \mathrm{mg}\right.$ TMA kg${ }^{-1}$ muscle) on Day 7 ,

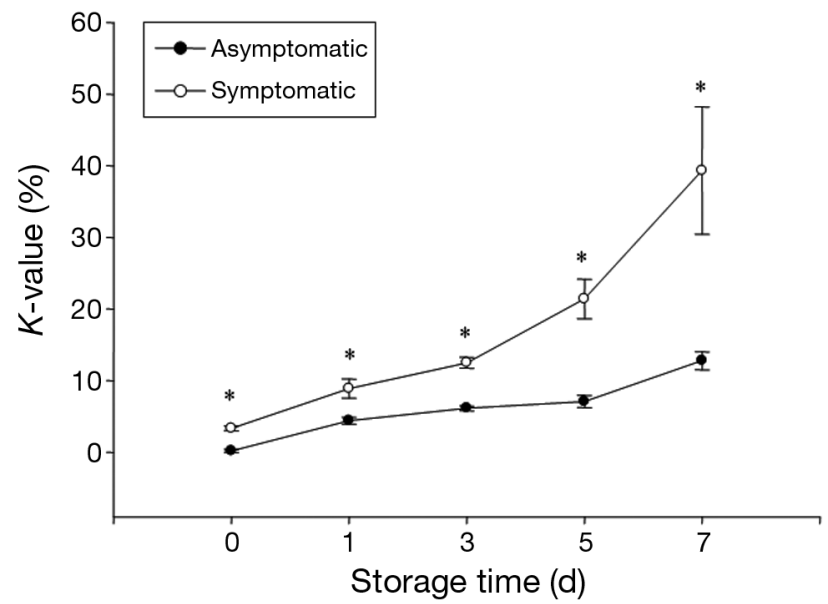

Fig. 2. $K$-values as freshness indicator in tail meat of asymptomatic and symptomatic Nephrops norvegicus stored on ice for $7 \mathrm{~d}$. Data are means $\pm \mathrm{SE}_{i} \mathrm{n}=5$. (*) Values are significantly different between asymptomatic and symptomatic $N$. norvegicus $(\mathrm{p}<0.05)$

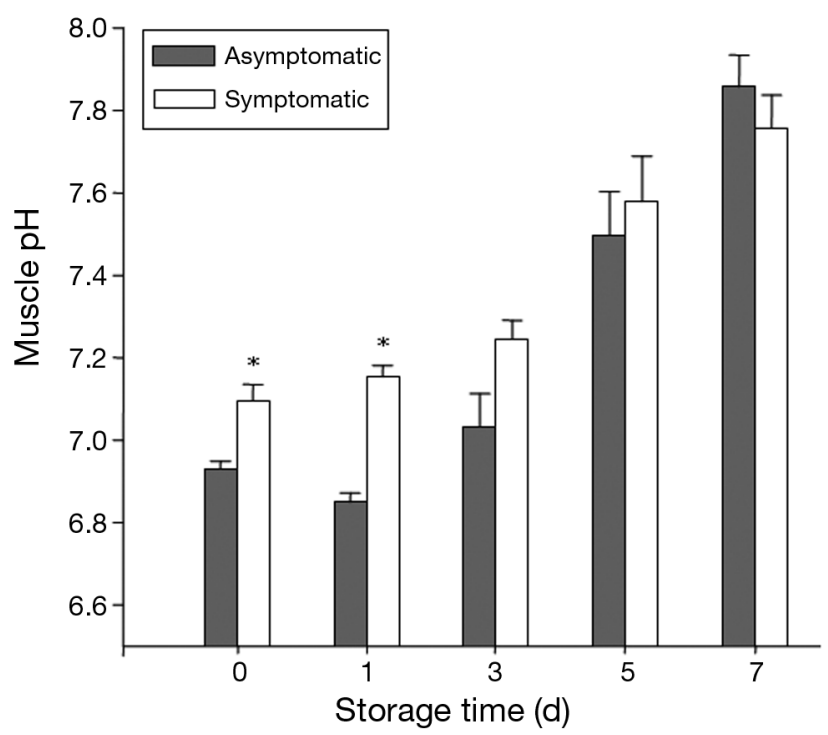

Fig. 3. pH of muscle homogenates from asymptomatic and symptomatic Nephrops norvegicus tails during ice storage for $7 \mathrm{~d}$. Data are means $\pm \mathrm{SE} ; \mathrm{n}=10$. (*) Values are significantly different between asymptomatic and symptomatic $N$. norvegicus $(\mathrm{p}<0.05)$ 
this difference was not statistically significant because of a high inter-individual variation (Fig. 5).

\section{Sensory evaluation of cooked product}

Cooked samples of asymptomatic and symptomatic Nephrops norvegicus tail meat were evaluated when fresh (i.e. Day 0) and on Day 5 of storage on ice (Table 2). In terms of aroma, a difference was observed between samples of symptomatic animals on Day 5 of storage on ice $(4.33 \pm 0.88$; appreciable sour-ammonia smell) compared to fresh samples of asymptomatic animals $(7.19 \pm 0.42$; fishy-seaweedy). However, in terms of smell strength, all samples were recorded as neutral or slightly strong, with values ranging from 5.81 to 6.54. Some differences were also recorded by the taste panel in terms of texture attributes. Samples from symptomatic animals were statistically softer (i.e. less resilient; $3.30 \pm 1.00$ ) and more friable (i.e. less firm; $4.45 \pm 0.74)$ than fresh samples from asymptomatic animals (6.67 \pm 0.59 and $7.18 \pm 0.43$, respectively). Moreover, samples from symptomatic animals on Day 5 of storage were statistically more tender (or less chewy; $4.29 \pm 0.86$ ) than samples from asymptomatic animals either when fresh $(7.03 \pm 0.53)$ or after storage to Day $5(6.86 \pm 0.64)$. However, no differences were obtained in moistness, with all samples being described as slightly moist (ranging from 5.75 to 6.17 ).

When scoring for flavour attributes, significant differences were found in flavour but not in aftertaste. Scores for the flavour of tail meat of infected animals when fresh and on Day 5 of storage (5.35 \pm 0.64 and $5.02 \pm 0.55$, respectively) were statistically lower than those for the flavour of tail meat of asymptomatic animals after capture $(6.63 \pm 0.52)$. The flavour of tail meat from symptomatic animals immediately after capture was described as bland, while that of tail meat from asymptomatic animals was described as sweet.

Finally, the taste panel was asked to subjectively score the 'degree of like or dislike' of the samples tested. Samples from symptomatic animals tended to score lower (values ranging from 3.67 to 4.39 ) than samples from asymptomatic animals (values ranging from 6.27 to 6.29 ) both after capture and also on Day 5 of storage on ice, although no significant differences were obtained because of high variability in the scoring.

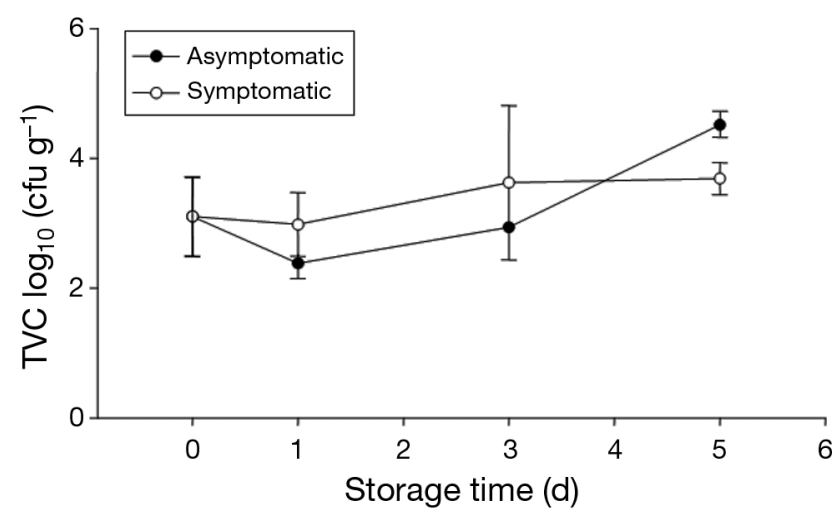

Fig. 4. Total viable count (TVC) concentrations in tail meat of asymptomatic and symptomatic Nephrops norvegicus stored on ice for $5 \mathrm{~d}$. Data are means $\pm \mathrm{SE}_{;} \mathrm{n}=5$

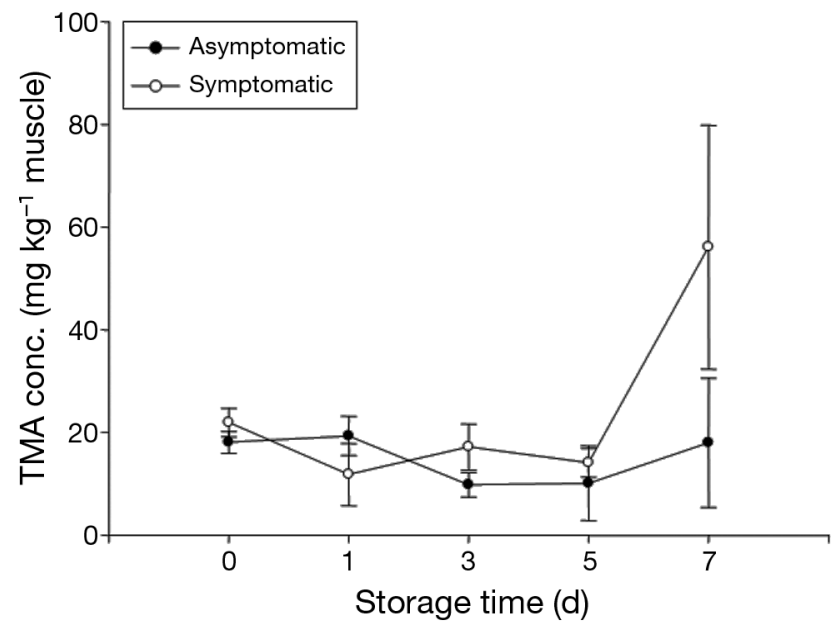

Fig. 5. Trimethylamine (TMA) concentrations in tail meat of asymptomatic and symptomatic Nephrops norvegicus stored on ice for $7 \mathrm{~d}$. Data are means $\pm \mathrm{SE}$; $\mathrm{n}=5$

Table 2. Quantitative descriptive analysis of cooked samples of tail meat of Nephrops norvegicus that were either asymptomatic or symptomatic of patent infection by Hematodinium sp. Samples were taken immediately after capture (Day 0) and on Day 5 of ice storage. In each row, values sharing a superscript letter are not significantly different $(p<0.05)$

\begin{tabular}{|llllll|}
\hline \multirow{2}{*}{ Attribute } & \multicolumn{3}{c}{ Day $0-$} & & \multirow{2}{*}{ Day 5} \\
\cline { 2 - 3 } \cline { 5 - 6 } & Asymptomatic & Symptomatic & & Asymptomatic & Symptomatic \\
\hline Smell character & $7.19 \pm 0.42^{\mathrm{a}}$ & $5.93 \pm 0.50^{\mathrm{a}, \mathrm{b}}$ & & $5.64 \pm 0.61^{\mathrm{a}, \mathrm{b}}$ & $4.33 \pm 0.88^{\mathrm{b}}$ \\
Smell strength & $6.54 \pm 0.50$ & $5.81 \pm 0.65$ & & $6.04 \pm 0.49$ & $5.92 \pm 1.03$ \\
Springiness & $6.67 \pm 0.59^{\mathrm{a}}$ & $5.27 \pm 0.79^{\mathrm{a}, \mathrm{b}}$ & & $5.04 \pm 0.72^{\mathrm{a}, \mathrm{b}}$ & $3.30 \pm 1.00^{\mathrm{b}}$ \\
Firmness & $7.18 \pm 0.43^{\mathrm{a}}$ & $6.94 \pm 0.88^{\mathrm{a}, \mathrm{b}}$ & & $6.74 \pm 0.60^{\mathrm{a}, \mathrm{b}}$ & $4.45 \pm 0.74^{\mathrm{b}}$ \\
Chewiness & $7.03 \pm 0.53^{\mathrm{a}}$ & $5.98 \pm 0.69^{\mathrm{a}, \mathrm{b}}$ & & $6.86 \pm 0.64^{\mathrm{a}}$ & $4.29 \pm 0.86^{\mathrm{b}}$ \\
Moistness & $5.93 \pm 0.76$ & $5.75 \pm 0.56$ & & $6.17 \pm 0.65$ & $5.78 \pm 0.56$ \\
Flavour & $6.63 \pm 0.52^{\mathrm{a}}$ & $5.35 \pm 0.64^{\mathrm{b}}$ & & $6.18 \pm 0.48^{\mathrm{a}, \mathrm{b}}$ & $5.02 \pm 0.55^{\mathrm{b}}$ \\
Aftertaste & $6.53 \pm 0.57$ & $5.22 \pm 0.70$ & & $5.62 \pm 0.40$ & $5.05 \pm 0.62$ \\
Overall liking & $6.27 \pm 0.68$ & $4.39 \pm 0.71$ & & $6.29 \pm 0.71$ & $3.67 \pm 1.05$ \\
\hline
\end{tabular}




\section{DISCUSSION}

The present study has shown for the first time that cooked tail meat from Nephrops norvegicus with advanced stages of Hematodinium sp. infection does not have a bitter taste. Rather, the sensory taste panel described the infected meat as having a bland taste and a bland aftertaste, both immediately after capture (Day 0) and after storage on ice for $5 \mathrm{~d}$. Additionally, significantly less sweetness was perceived in the flavour and aftertaste of the tail meat from symptomatic compared with asymptomatic $N$. norvegicus, both after capture and on Day 5 of storage on ice. These results suggest that a change in the composition of the tail meat driven by the infection affects the sweetness of the cooked product, although not to an extent to be described as bitter.

Non-volatile taste-active compounds in crustacean muscle include free amino acids, nucleotides, soluble sugars, organic acids and minerals (Hayashi et al. 1981, Chen \& Zhang 2007). In this context, Stentiford et al. (2000) found an altered free amino acid profile and depleted glycogen in muscles from infected Nephrops norvegicus, which could explain at least in part the detected loss in sweetness. Other compounds such as AMP and IMP have been related to the pleasant 'umami' taste (Hayashi et al. 1981). However, as fresh samples (Day 0) of patently infected $N$. norvegicus had considerable levels of both nucleotides, there may be other compounds from the parasite itself or present in infected muscle that was not analysed in this study that may have a greater impact on flavour than nucleotides.

Other clear changes noted by the taste panel were alterations in the texture. Tail meat from symptomatic animals was softer, more friable and more tender than that from asymptomatic ones. These changes in texture are in agreement with previous studies on lobsters and could be explained by the damage and tissue destruction that high numbers of Hematodinium spp. cause to the host in the late stages of infection (Field et al. 1992, Stentiford et al. 2002, Stentiford \& Shields 2005). Changes in taste and especially texture reduced the overall liking of the samples, which confirms the poorer quality of infected Nephrops norvegicus for marketing.

Quality-related analytical assays of infected tail meat indicate several points. After capture, tail meat from symptomatic animals had significantly higher $\mathrm{pH}$ values and IMP and HxR concentrations than tail meat from asymptomatic animals. The effects of trawling on Nephrops norvegicus have been extensively studied (Harris \& Andrews 2005, Ridgway et al. 2006, Albalat et al. 2009). Trawled N. norvegicus have AMP as the main nucleotide in the muscle instead of ATP, because of the activation of anaerobic glycolysis (Albalat et al. 2009). As a result of this activation of anaerobic metabolism, glycogen in trawled animals decreases, L-lactate accumulates and as a result muscle $\mathrm{pH}$ also decreases (Ridgway et al. 2006, Gornik et al. 2008, Albalat et al. 2009). This was the case in tail meat of asymptomatic animals. However, in symptomatic $N$. norvegicus this fall in muscle $\mathrm{pH}$ after trawling was not as clear, and therefore muscle $\mathrm{pH}$ in these patently infected animals was significantly higher. This result would be in agreement with other studies that have found that infected $N$. norvegicus have depleted glycogen in the muscle (Stentiford et al. 2000, Gornik et al. 2010). As a consequence, N. norvegicus heavily infected with Hematodinium sp. cannot activate anaerobic glycolysis to produce ATP (Gornik et al. 2010), and so in situations of high demand, such as those induced by the stress of trawling, L-lactate is not produced and no decrease is observed in muscle $\mathrm{pH}$. Furthermore, as AMP is transformed to IMP (very apparent in infected animals immediately after capture) ammonia will be released, possibly shifting muscle $\mathrm{pH}$ to a less acidic state in this group (Huss 1995).

It is intriguing that IMP was one of the main nucleotides in infected animals after capture. In general, it is known that when crustaceans are subjected to stress situations such as trawling, AMP tends to accumulate instead of IMP (Mendes et al. 2001, Albalat et al. 2009) because of a reduced activity of the enzyme AMP-deaminase, which is responsible for the conversion of AMP to IMP (Raffin \& Thebault 1987). However, other authors have pointed out that in situations where no or a very slow glycolytic response takes place (owing to the absence of glycogen), IMP can be accumulated at a faster rate, since the AMP-deaminase system becomes over-activated and IMP is accumulated in order to reduce the AMP burden. This could explain why IMP was higher in infected animals (Gornik et al. 2010). In crustaceans, IMP has been described as a marker of muscular fatigue and an indicator of a compromised physiological state due to extreme stresses (Chen et al. 1990, Paterson 1993). The fact that this nucleotide was higher in symptomatic Nephrops norvegicus after capture is therefore consistent with the finding that at advanced stages of infection this parasite totally depletes the energy stores of the host, inducing a state of physiological collapse (Stentiford et al. 2000). 
Altogether, it appears that tail muscle of symptomatic animals is in a more advanced autolytic stage, and therefore the meat of these patently infected animals seems less fresh after capture, a trend that is maintained throughout the storage time on ice, as also shown by higher $K$-values in this group. The $K$ value has been commonly used as 'freshness indicator' in seafood for many years, and so results from this study indicate that freshness is lost at a faster rate in tail meat from symptomatic compared to asymptomatic animals.

However, despite the fact that the autolytic postmortem events in tail meat of infected animals occurred more rapidly, bacterial load accumulation and the rate of increase of concentrations of TMA, a compound mainly produced by the action of certain spoiling bacteria, were similar between tail meats from asymptomatic and symptomatic Nephrops norvegicus. Thus, these results suggest that the changes perceived by the sensory taste panel were mainly due to the Hematodinium sp. infection, and not to a secondary bacterial infection that could have been induced by the presence of the parasite.

In summary, tail meat from Nephrops norvegicus symptomatic of patent Hematodinium sp. infection is more bland in flavour and aftertaste and has a more friable or sloppier texture than tail meat from asymptomatic animals. As a consequence, tail meat from the patently infected animals tends to be less desirable, indicating the poorer quality of these animals for marketing. From an analytical point of view, the tail meat from heavily infected animals was at a more advanced phase of autolysis. Moreover, the scores from the panel were due to the Hematodinium sp. infection itself, since microbial growth and its associated tissue breakdown were similar in both groups. However, because this study has found that advanced stages of Hematodinium sp. infection in N. norvegicus do not confer a bitter taste to the tail meat, it seems inappropriate to apply a term equivalent to $\mathrm{BCD}$ to this species. In fact, for the sake of comparison, a full organoleptic assessment of the BCD syndrome in various crab species would be informative, and would test the validity of this descriptive term for Hematodinium spp. infections in crab species.

Acknowledgements. The authors thank the crew of the RV 'Aora' for their assistance in the collection of trawled animals and M. Saadat of the Food Innovation Institute for his work on the sensory assessment. This work was supported by a grant from the EU Financial Instrument for Fisheries Guidance (FIFG) Scheme through the Scottish Executive, and by Young's Seafood.

\section{LITERATURE CITED}

Albalat A, Gornik SG, Atkinson RJA, Coombs GH, Neil DM (2009) Effect of capture method on the physiology and nucleotide breakdown products in the Norway lobster (Nephrops norvegicus). Mar Biol Res 5:441-450

Albalat A, Gornik SG, Mullen W, Crozier A, Atkinson RJA, Coombs GH, Neil DM (2011) Quality changes in chilled Norway lobster (Nephrops norvegicus) tail meat and the effects of delayed icing. Int J Food Sci Technol 46: 1413-1421

Beevers ND, Kilbride E, Atkinson RJA, Neil DM (2012) Hematodinium infection seasonality in the Firth of Clyde (Scotland) Nephrops norvegicus population: a reevaluation. Dis Aquat Org 100:95-104

Briggs RP, McAliskey M (2002) The prevalence of Hematodinium in Nephrops norvegicus from the western Irish Sea. J Mar Biol Assoc UK 82:427-433

Chen DW, Zhang M (2007) Non-volatile taste active compounds in the meat of Chinese mitten crab (Eriocheir sinensis). Food Chem 104:1200-1205

> Chen HC, Moody MW, Jiang ST (1990) Changes in biochemical and bacteriological quality of grass prawn during transportation by icing and oxygenation. J Food Sci 55:670-673

Chiou TK, Huang JP (2004) Biochemical changes in the abdominal muscle of mud crab Scylla serrata during storage. Fish Sci 70:167-173

Dyer WJ (1945) Amines in fish muscle. I. Colorimetric determination of trimethylamine as the picrate salt. J Fish Res Board Can 6d:351-358

Field RH, Appleton PL (1995) A Hematodinium-like dinoflagellate infection of the Norway lobster Neprhops norvegicus: observations on pathology and progression of infection. Dis Aquat Org 22:115-128

Field RH, Chapman CJ, Taylor AC, Neil DM, Vickerman K (1992) Infection of the Norway lobster Nephrops norvegicus by a Hematodinium-like species of dinoflagellate on the west coast of Scotland. Dis Aquat Org 13: $1-15$

FRS (Fisheries Research Services) (2009) Fish and Nephrops stock information. FRS Information Resources, Aberdeen, p 45

Gornik SG, Albalat A, Atkinson RJA, Coombs GH, Neil DM (2008) Early post-mortem processes in the abdominal muscle of the Norway lobster (Nephrops norvegicus). Mar Freshw Behav Physiol 41:241-256

Gornik SG, Albalat A, Atkinson RJA, Coombs GH, Neil DM (2010) The influence of ante-mortem stressors on the early post-mortem processes in the abdominal muscle of Norway lobster (Nephrops norvegicus). Mar Biol Res 6: 223-238

Hamilton K, Shaw PW, Morritt D (2009) Prevalence and seasonality of Hematodinium (Alveolata: Syndinea) in a Scottish crustacean community. ICES J Mar Sci 46:17-28

$>$ Harris RR, Andrews MB (2005) Physiological changes in the Norway lobster Nephrops norvegicus (L.) escaping and discarded from commercial trawls on the west coast of Scotland II. Disturbances in haemolymph respiratory gases, tissue metabolites and swimming performance after capture and during recovery. J Exp Mar Biol Ecol 320:195-210

> Hayashi T, Yamaguchi K, Konosu S (1981) Sensory analysis of taste-active components in the extract of boiled snow crab meat. J Food Sci 46:479-484 
Huss HH (1995) Quality and quality changes in fresh fish. FAO Fisheries Technical Paper 348. Available at www. fao.org/docrep/V7180E/V7180E00.htm

Latrouite D, Morizur Y, Nöel P, Chagot D, Wihelm G (1988) Mortalite du tourteau Cancer pagurus provoquee par le dinoglagellate parasite: Hematodinium sp. Cons Int Explor Mer CM 1988/K:32

Love DC, Rice SD, Moles DA, Eaton WD (1993) Seasonal prevalence and intensity of bitter crab dinoflagellate infection and host mortality in Alaskan Tanner crabs Chionoecetes bairdi from Auke Bay, Alaska, USA. Dis Aquat Org 15:1-7

Mendes R, Quinta R, Nunes ML (2001) Changes in baseline nucleotides during ice storage of fish and crustaceans from the Portuguese coast. Eur Food Res Technol 212: 141-146

Messick GA (1994) Hematodinium perezi infections in adult and juvenile blue crabs Callinectes sapidus from coastal bays of Maryland and Virginia, USA. Dis Aquat Org 19: $77-82$

Meyers TR, Koeneman TM, Botelho C, Short S (1987) Bitter crab disease: a fatal dinoflagellate infection and marketing problem for Alaskan Tanner crabs Chionoecetes bairdi. Dis Aquat Org 3:195-216

> Meyers TR, Botelho C, Koeneman TM, Short S, Imamura K (1990) Distribution of bitter crab dinoflagellate syndrome in southeast Alaskan Tanner crabs Chionoecetes bairdi. Dis Aquat Org 9:37-43

Paterson BD (1993) The rise in inosine monophosphate and L-lactate concentrations in muscle of live penaeid prawns (Penaeus japonicus, Penaeus monodon) stressed by storage out of water. Comp Biochem Physiol 106A: 395-400

Raffin JP, Thebault MT (1987) Purification and partial characterization of an AMP deaminase from the marine invertebrate Palaemon serratus. Comp Biochem Physiol 88B:1071-1076

Ridgway ID, Taylor AC, Atkinson RJA, Chang ES, Neil DM (2006) Impact of capture method and trawl duration on the health status of the Norway lobster, Nephrops norvegicus. J Exp Mar Biol Ecol 339:135-147

Ryazanova TV (2008) Bitter crab syndrome in two species of king crabs from the Sea of Okhotsk. Russ J Mar Biol 34: 411-414

Ryder JM (1985) Determination of adenosine triphosphate and its breakdown products in fish muscle by high-performance liquid chromatography. J Agric Food Chem 33: $678-680$

Saito T, Arai K, Matsuyoshi M (1959) A new method for the

Editorial responsibility: Grant Stentiford,

Weymouth, UK estimation of the freshness of fish. Bull Jpn Soc Sci Fish 24:749-750

Shields JD, Taylor DM, Sutton SG, O'Keefe PG, Ings DW, Pardy AL (2005) Epidemiology of bitter crab disease (Hematodinium sp.) in snow crabs Chionoecetes opilio from Newfoundland, Canada. Dis Aquat Org 64:253-264

Small HJ, Wilson S, Neil DM, Hagen P, Coombs GH (2002) Detection of the parasitic dinoflagellate Hematodinium in the Norway lobster Nephrops novegicus by ELISA. Dis Aquat Org 52:175-177

Stentiford GD, Neil DM (2011) Diseases of Nephrops and Metanephrops: a review. J Invertebr Pathol 106:92-109

Stentiford GD, Shields JD (2005) A review of the parasitic dinoflagellates Hematodinium species and Hematodinium-like infections in marine crustaceans. Dis Aquat Org 66:47-70

Stentiford GD, Neil DM, Coombs GH (1999) Changes in the plasma free amino acid profile of the Norway lobster Nephrops norvegicus at different stages of infection by a parasitic dinoflagellate (genus Hematodinium). Dis Aquat Org 38:151-157

Stentiford GD, Neil DM, Coombs GH (2000) Alterations in the biochemistry and ultrastructure of the deep abdominal flexor muscle of the Norway lobster Nephrops norvegicus during infection by a parasitic dinoflagellate of the genus Hematodinium. Dis Aquat Org 42:133-141

Stentiford GD, Neil DM, Coombs GH (2001a) Development and application of an immunoassay diagnostic technique for studying Hematodinium infections in Nephrops norvegicus populations. Dis Aquat Org 46:223-229

Stentiford GD, Chang ES, Chang SA, Neil DM (2001b) Carbohydrate dynamics and the crustacean hyperglycaemic hormone $(\mathrm{CHH})$ : effects of parasitic infection in Norway lobsters (Nephrops norvegicus). Gen Comp Endocrinol 121:13-22

Stentiford GD, Green M, Bateman K, Small HJ, Neil DM, Feist SW (2002) Infection by a Hematodinium-like parasitic dinoflagellate causes pink crab disease (PCD) in the edible crab Cancer pagurus. J Invertebr Pathol 79: 179-191

Stroud GD, Early JC, Smith GL (1982) Chemical and sensory changes in iced Nephrops norvegicus as indices of spoilage. Int J Food Sci Technol 17:541-551

Wilhelm G, Mialhe E (1996) Dinoflagellate infection associated with the decline of Necora puber crab populations in France. Dis Aquat Org 26:213-219

> Xu WJ, Xie J, Shi H, Li C (2010) Hematodinium infections in cultured ridgetail white prawns, Exopalaemon carinicauda, in Eastern China. Aquaculture 300:25-31

Submitted: March 12, 2012; Accepted: June 28, 2012

Proofs received from author(s): August 21, 2012 